\title{
The Economics of Female Piety in Early Sufism
}

\author{
Arin Salamah-Qudsi (D)
}

check for updates

Citation: Salamah-Qudsi, Arin. 2021. The Economics of Female Piety in Early Sufism. Religions 12: 760. https://doi.org/10.3390/rel12090760

Academic Editors: Milad Milani, Zahra Taheri and Aydogan Kars

Received: 28 July 2021

Accepted: 9 September 2021

Published: 13 September 2021

Publisher's Note: MDPI stays neutral with regard to jurisdictional claims in published maps and institutional affiliations.

Copyright: (C) 2021 by the author. Licensee MDPI, Basel, Switzerland. This article is an open access article distributed under the terms and conditions of the Creative Commons Attribution (CC BY) license (https:// creativecommons.org/licenses/by/ $4.0 /)$.
Department of Arabic Language and Literature, University of Haifa, Haifa 3498838, Israel; arinsq@gmail.com

\begin{abstract}
This paper examines the economics of female piety between the third/ninth and sixth/twelfth centuries. It traces Sufi approaches to poverty and working for a living (kasb) as well as kasb's intersection with marriage and women. Rereading Sufi and non-Sufi biographies and historiographies reveals that there were wealthy women who initiated marriage with renowned Sufis to gain spiritual blessings, and others who financially supported their husbands. While the piety of male Sufis was usually asserted through material poverty, the piety of female mystics was asserted through wealth and almsgiving. This paper examines this piety through different female kinships—whether mothers, wives or sisters. Similar to the spousal support of wives for their husbands, sisters very often acted as an impressive backup system for their Sufi brothers. Mothers, however, effected a great socio-religious impact through the cherished principles of a mother's right to control her son and a son's duty to venerate his mother. This devotion was often constraining financially and Sufis needed to pay attention to the financial implications while still pursuing progress on the Sufi path.
\end{abstract}

Keywords: arfāq al-niswān (women's donations); sisters; mothers; haqq al-wālida (mother's right); poverty; charity; khidma (service)

\section{Introduction: Changing Approaches to Poverty, Wealth and Renunciation in Early Sufism}

Female pietists who lived and acted in Iraq and Syria during the first centuries of Islam did not leave us any documents in their own right. All we have comes from later compendia and biographical collections written by male historians and biographers. Given the common notion that studying the history of women in Islam is almost impossible due to the lack of sources written on women and by women, Afsaneh Najmabadi has shown that "if we use gender analytically, sources about men are also sources about women" (Najmabadi 2005, p. 1).

Prior to the early phase of tașawwuf, female ascetics played active roles in the general fabric of Islamic piety and the early tradition of renunciation (zuhd). In his significant paper on female renunciants that lived before the crystallization of classical Sufism in the third/ninth century, Christopher Melchert notes that no works survive from female Sufis or renunciants, not even later references to lost works (Melchert 2016, p. 116). What we do have is dated from the fourth/tenth century onward and consists of a bulk of sayings and anecdotes relating to earlier pious women in Sufi biographies, textbooks and non-Sufi works of belles-lettres ( $a d a b$ ), historiographies and hadith collections of the fourth/tenth century and onward. In this paper, I do not focus on the question of whether the devotional practices and morality of those women constituted either a particular, gender-specific or non-gender-specific common mode of piety. Instead, my paper concentrates on the economics of women's involvement in early Islamic piety and tașawwuf. The time span studied in this paper is between the third/ninth and sixth/twelfth centuries. This paper is a further attempt to raise new questions about the role of women as economic agents. It does so in spite of the lack of sources that could support any full-fledged process of reconstruction. Our main sources are Sufi hagiographies and Islamic biographies, which provide some historical clues and insights (Silvers 2015, p. 26; Curry and Ohlander 2012, pp. 1-14; Salamah-Qudsi 2019, pp. 16-18). Hagiographies enable us to observe changing 
mindsets, tendencies and approaches towards pious women in medieval Islamic society. This positive approach towards Sufi hagiographies as significant sources conveying some socio-historical implications builds on recent scholarly endeavors made by Jürgen Paul, Vincent Cornell, Catherine Mayeur-Jaouen, Alexandre Papas and others.

"Economics" is all about conditions and perceptions of wealth-its production, consumption and distribution. In its cultural dimension, economics also deals with how people interact in terms of values, utility and prosperity. Cultural relationships and processes can also be seen to exist within an economic environment and can themselves be interpreted in economic terms (Throsby 2001, p. 10).

Being a solid system of beliefs, customs and practices, Sufism from its very beginnings identified itself by establishing particular approaches towards owning properties, working for one's living and seeking money, leadership and power (Sabra 2021, p. 27). The early Sufi institution embedded different forms of the transaction of properties among its members, guiding masters and followers. Sufis succeeded in the course of the fourth/tenth and fifth/eleventh centuries to crystallize their collective identity through a massive process of theorization (composition of textbooks and comprehensive manuals) as well as the establishment of particular public spaces in the form of Sufi lodges (Karamustafa 2007, p. 7; Salamah-Qudsi 2019, pp. 3-9). This was accompanied by sessions of learning and the transmission of Sufi doctrines that massively helped adherents put into practice their devotional values and collective spiritual morals across the entire Islamic landscape. The early Sufi textbooks present detailed discussions of the kinds of donations rich and noble people used to give to Sufis (Khan 2021, p. 81).

According to an early and well-documented Sufi ideal, economic prosperity is not an indicator for any spiritual prosperity; in fact, it could be an obstacle to experiencing the higher inner states and revelations along the Sufi path (Reinert 1968, p. 40; Massignon 1954, pp. 258-60). One's search for wealth is very often conceived as a manifestation of being subordinated to one's lower soul (nafs), the inner faculty, which is filled with weakness in the face of momentary luxuries and material pleasures. Poverty (faqr), therefore, is the preferable value and ideal lifestyle according to the early Sufi system of thought. It is the essential aspect of withdrawing from the world and being both perfectly devoted to God and radically dependent on Him. It is an indication of one's being chosen by God, of one's neediness of material pleasures of this world and of one's passionate quest for spiritual closeness and illuminations.

Furthermore, the very quest for wealth contradicts the necessity of living the Sufi moment (waqt). Waqt is an early technical term in Sufi thought and indicates a transitory state of experiencing revelations and spiritual observations. "The Sufi lives in the present moment", a fundamental principle asserted frequently in the early Sufi compendia (al-Sarrāj al-Ṭūsī 1914, p. 396; al-Qushayrī 1940, p. 33; al-Hujwīrī al-Jullābī 1926, pp. 480-84). Living that mystic moment is attained through separating oneself from both the past and the future. Al-Ghazālī (d. 555/1111), for instance, was eager to emphasize that working for subsistence, very often, makes the mystic subject to doubtful matters (shubuhāt) whose origins and purposes are not legal or spiritually sincere and might even be infected by the ambitions of the lower soul (al-Ghazālī n.d., vol. 2, pp. 102 ff.). One of the most famous anecdotes about the sisters of Bishr ibn al-Hārith (d. c. 767/841), an early renunciant-mystic of Merv, relates their request for an advisory opinion from Ahmad ibn Hanbal regarding the legality of their work in spinning on the roofs of their house. The question here is whether one could make use of the soldiers' torches that lit up the area since those soldiers were representatives of the state and making use of that light would indicate dependence on the state (al-Qushayrī 1940, p. 59).

In many Sufi textbooks, poverty lies as one of the elementary conditions for embarking upon the Sufi path, and one of the first steps of those who seek God. These textbooks are fraught with anecdotes about renunciant-mystics who used to publicly celebrate their very commitment to poverty. When a man sought to give Ibrāhīm b. Adham (d. 161/777) a sum of money, the latter harshly rejected the gift, telling the man: "Do you want to 
erase my name from the poor list for ten thousands dirhams? I will not let you do so." (al-Qushayrī 1940, p. 134).

While material poverty was one of the renunciatory customs that lay at the very basis of early tasawwuf (on the essential renunciatory features of Sufism, see Knysh 2017, pp. 15-34), a debate is reported on which is preferable in living a mystic life: poverty or wealth. Besides the common approach cited above giving priority to poverty, there were some who disagreed and who gave wealth priority. They argued that because one of God's names is the Ghanī, i.e., the self-sufficient, wealth is preferable while poverty has nothing to do with God's attributes and names (al-Qushayrī 1940, p. 135; al-Sarrāj al-T̄ūsī 1914, pp. 411-13; al-Suhrawardi 1977, pp. 6-7. On the positive attitudes towards wealth in Sufism, see Sabra 2021, pp. 29-30; Hofer 2015, p. 146).

During early Islam, poverty was valued in the eyes of early ascetics not for its own sake itself but "as a condition of existence determined by God, just as wealth". This means that voluntary poverty, the material type of poverty that ascetics strive for, was not a common practice as has long been thought (Cornel 2019, pp. 114-20). In third/ninth century Sufism, voluntary poverty became widely celebrated. The character of Abū Bakr al-Ṣiddīq, the great companion of the Prophet Muhammad, who chose to forego his properties for the sake of the community of believers, was portrayed as the prototype of voluntary poverty (al-Hujwīìn al-Jullābī 1976, p. 71).

In the Sufi writings of the fourth/tenth and fifth/eleventh centuries, two major dynamics occur. The first relates to an attempt to emphasize the existence of a sublime state in which the mystic abandons one's own will and fulfils God's will whatever that will is. If the mystic is granted wealth, he/she should not reject it but fully surrender to God's will and accept it (1991, p. 55; al-Suhrawardī 1967, p. 364). The second dynamic relates to an interesting process in which the principle of poverty was gradually given more inner and even symbolic implications. Spiritual poverty would ideally have the mystic choose to mentally forego the acquisition of possessions and wealth even were he/she actually wealthy. Different attempts to classify material poverty into different stages were presented. According to one made by al-Hujwīrin, for instance, there are two levels of poverty: the first is compulsory, while the other, the higher, is voluntary and chosen by the mystic in spite of his life circumstances of wealth (al-Hujwīrī al-Jullābī 1976, p. 71).

Sufi poverty, according to some early discussions, was divided into three degrees, the highest of which is merely attainable by a small elite of true mystics who do "not possess and are possessed by anything [originally, nothing possess him/them!]" (al-Sarrāj al-Ṭūsī 1914, p. 25; al-Makkī 2005, vol. 1, p. 447). Adam Sabra surveys the different doctrines starting with the early Sufi authors through to al-Ghazālī and concluding with Abū Hafs al-Suhrawardī (d. 632/1234), the outstanding and most influential master of Baghdad during the later sixth/twelfth century. As for al-Suhrawardī, Sabra asserts that his discussion of poverty is "brief and original" (Sabra 2000, p. 26). While I do not think al-Suhrawardi's discussion of poverty was actually brief, I do agree that it was novel. Al-Suhrawardī relates to poverty as part of his profound discussions of renunciation (zuhd). He indicates that there are three degrees of zuhd, the highest of which is the zuhd thālith (the third degree of renunciation), which allows the mystic to have material wealth while keeping the sublime title of "poor", faqir. This means that the acquisition of possessions can no longer harm the mystic since the mystic is not controlled by that wealth or the engagements and commitments that are tied to that wealth. This notion explains in fact why the lodges of the Suhrawardiyya order in India and Persia were commonly known as very luxurious in comparison with those of the Chishtiyya order (Digby 1986, p. 64; Nizami 1961, pp. 223-24).

In addition to the question of poverty and its definition, constraints and lived reality, the economics of early Sufis also concerns itself with one's working for subsistence (kasb), almsgiving, begging and financial backing for one's family members-whether new initiates or masters in Sufi communities. This financial support includes the institution of service, khidma, of giving rest to and guaranteeing the living of a group of disciplined Sufis 
who live together in a Sufi lodge and who commit themselves to devotional life. Serving one's "brothers" means that one supports their ritual activities, gatherings for meals and almsgiving for their families; all this is undertaken while these "brothers" are committed to a life of renunciatory journeys and constant roving to effect the noble principle of tawakkul (absolute dependence on God). I will return to this phenomenon, khidma, and its economic dimensions later on.

\section{Between Working for a Livelihood and Celibacy}

In the course of the third/ninth century, the Islamic landscape witnessed sophisticated debates over the controversial nature of earning one's livelihood and its conflict with the principle of absolute dependence on God (tawakkul). In the eastern territories of Islam, such discussions came to be highly influenced by karrämiyya's tendency to practice a rigid mode of renunciatory life in which abandoning work was an integral part. M. Malamud points to the most common inquiries that arose among karrām $\bar{\imath}$ and non-karrāmi ascetics in that period, all of which found their appearance in the writings of early Sufis: How could $k a s b$ be reconciled with a life of total renunciation? Was voluntary poverty seen as better than earning a living? Did the Muslim renunciant need to reconcile the very basis of one's religious life, one's total dependence on God, with the well-established fashion of earning one's living and supporting families and children? How would the renunciant understand the complete body of Qur'ānic verses and prophetic traditions supporting kasb?

The principle of tark al-kasb, not working for a living, had great influence upon Sufism in general in the period under discussion. It also left its mark on those Sufis who did earn a living and support families. Abū 'Abd al-Rahmān al-Sulamī (d. 412/1021) refers to the fourth/tenth century Sufi of Nishapur, Abū 'Amr al-Zajjajjī (d. 348/959), who urged one of his companions to get married since the observance of the prophetic tradition of marriage would open the doors of livelihood (rizq) for him (al-Sulamī 1976, p. 27). Such a notion implies that the fear of marriage's economic responsibilities was a serious consideration for early mystics. Marriage could hardly be experienced without earning one's living. Recent research of the nature of marital relationships during medieval Islam has drawn on different types of early sources to show that the institution of Islamic medieval marriage was, in fact, "fluid", with high rates of divorce and an increasing number of single women who could support themselves independently (Rapoport 2005, pp. 38-44). The issue of large dowries that were imposed upon men was even raised by the fourth/tenth century Sufi author Abū Ṭālib al-Makkī (d. 386/996) in a detailed chapter in his textbook Qūt al$q u l \bar{u} b$ (The Nourishment of the Hearts) that he devotes to marriage and celibacy. al-Makkī refers to the economic difficulty that young men had to face before marriage. Unlike slave women ( $\left.i m \bar{a}^{\prime}\right)$ who could be taken as wives without dowry, free women required large dowries. Coupled with having to endure the inflexible demands of family commitments and livelihood, $Q \bar{u} t a l-q u l \bar{u} b$ presents a reality in which poor, young Sufis preferred to remain celibate for long periods of their lives (al-Makkī 2005, vol. 2, pp. 398-99). Celibacy seemed to al-Makkī wholly acceptable, particularly in light of the fact that it was becoming more and more difficult in his days to earn money and support families without being involved in illegal acts.

Other early Sufi sources imply that among those who married, there were two groups of Sufis: one whose members worked to gain their livelihood normatively, and the other whose members chose to abandon kasb and turned to alms and charity to support their families. In addition to al-Makkī, al-Sarrāj severely criticizes this phenomenon (al-Sarrāj al-Ṭūsī 1914, p. 200; al-Makkī 2005, vol. 1, p. 333). This criticism was occasionally met by attempts to fabricate support amongst early Sufis. One of the few personalities in early Sufism who likely stayed celibate for his entire life, Ibrāhīm b. Adham, appears in Khargūshī's (d. c. 407/1016) textbook Tahdhīb al-asrār and is reputed to have emphasized the high rank of those who worked for a living, supported their families and supplied their children with sustenance. Ibrāhīm supposedly urged his fellows to work as heroes ('alayka bi-'amal al-abtāl) for their children's sustenance (nafaqa 'alā al-'iyāl) 
(al-Khargūshì 1999, p. 299). The disconnect between his life and these statements renders these statements highly improbable. Abū al-Hasan al-Shādhilī (d. 656/1258) urged his followers to continue to pursue their professions and avoid accepting alms or gifts (Sabra 2021, pp. 29-30).

The criticism addressed to the early mystic of Baghdad Ruwaym b. Ahmad (d. 303/915) by his contemporary Sufi fellows was, most probably, motivated by his involvement in state affairs and his acceptance of the position of deputy for the $q \bar{a} d \bar{\imath}$ of Baghdad. It is highly unlikely that any criticism was the result of his unique teachings on tawakkul and family life. Ruwaym did not believe that his involvement in the state's administration would damage his devotional life. He further rejected his critics by publicly being devoted to his children and their support. In response to those who claimed that he was thereby turning "away from the way of the hereafter by choosing the way of this world," Ruwaym said: "My brothers want me to be completely committed to the principle of tawakkul, and to avoid taking care of my daughter and of raising her." In the latter part of the quotation, he emphasizes his success to attain exalted spiritual states that none of his contemporary Sufis was able to attain (al-Daylamī 1977, 152).

In light of the ambivalent approach towards working for a living in early Sufism, temporal celibacy was widely adopted with paralleled theoretical support in Sufi literature (Salamah-Qudsi 2019, pp. 39-44). More and more explicit critical references to marriage and the essential contradiction it imposed with one's devotional engagements were clearly reported (al-Hujwīrī al-Jullābī 1976, p. 364). At one point in his rules of ethics concerning married Sufis with families, Abū Nașr al-Sarrāj indicates that even where wives are wealthy, true Sufis do not live at their wives' expense. "Laysa min ādābihim an yatazawwajū dhawāat al-yasāri wa-yadkhulu fi riffai nisā'ihim" (it is not one of their rules of ethics to marry wealthy women and to let themselves enjoy the wealth of their wives) (al-Sarrāj al-Ṭūsī 1914, p. 200). The sentence is not only meant to discourage Sufis from living off their wives, but can also be interpreted as discouraging them from even marrying such women. According to al-Sarrāj, a true Sufi should preferably marry a poor woman; however, in the case that a rich woman wishes to marry him, he should avoid her wealth and entirely detach himself from her properties and possessions. This notion does in fact strengthen the assumption that many wealthy women in the period examined here wanted to attain the spiritual blessings (baraka) of renowned mystics through the bonds of marriage. Some wealthy women even initiated the marriage by explicitly asking pious figures to marry them. This was the case of Umm Alī Fāțima of Balkh who, according to al-Hujwīrì, sent a messenger to the famous mystic of Balkh, Aḥmad b. Khaḍunya al-Balkhī (d. 240/854-855), to ask him to give her the honor of marrying her and allowing her to financially support him and his fellows. When Ahmad rejected her proposal, she was upset and sent the messenger back to him to tell him that, being a renowned mystic, he was expected to take responsibility in sincerely guiding people instead of putting obstacles in their path to God. Overwhelmed by this claim, Aḥmad changed his mind and married her (al-Hujwīrī al-Jullābī 1976, pp. 119-20). Interestingly, Arezou Azad, who deeply examines the case of Umm 'Alī, has shown that the latter's practice of strategic marriage enabled her to obtain access to the highest sources of learning (Azad 2013, p. 53).

Before al-Hujwīiñ, al-Sulamī introduced Umm 'Alī in his biographical dictionary of early Sufi women, Dhikr al-niswa, as a pious, wealthy woman, a daughter of nobility, who spent all of her money helping poor Sufis as well as her husband Ahmad and the demands of his devotional life (kānat mūsiratan fa-anfaqat mālahā kullahu 'alā al-fuqarā', wa-sā'adat Ahmad 'alā mā huwa 'alayhi) (al-Sulamī 1999, p. 169).

Despite their limited access to public space, women during early medieval Islam were not passive economic actors. Their involvement in economic life was impressive (Shatzmiller 1988, p. 58) and their being agents of economic and social growth has been increasingly acknowledged by recent studies with socio-historical approaches (such as Azad 2013; Roded 1999; El-Cheikh 2002; Marén and Deguilhem 2002). The economic prosperity of a large number of female Sufis and their profound interest in charity succeeded, 
in the course of time, to become an effective form of carrying out the moralistic dimensions of poverty. It increasingly involved female pietists and lay in parallel to the earlier, yet material form of poverty for male Sufis and renunciants. While many male Sufis preferred to maintain material poverty by abstaining from work, there was a group of female pietists who were wealthy enough to serve as strong financial backing for their male relatives, whether husbands, brothers or sons. It was through both this giving mindset and the effective institution of charity that the ideal of spiritual faqr was actualized in the work and practice of the female mystics of Islam.

\section{Female Prosperity, Charity and Economic Authority}

A debate over the existence or absence of a distinctive female piety during the classical period of Sufism is still ongoing. Female scholars, such as Ruth Roded, Rkia Cornell, Arezou Azad and Maria Dakake, emphasize, each in her own way, the existence of different traits and virtues of Islamic female piety: a common "language of domesticity" according to Dakake (Dakake 2007, p. 72), or a common "theology of servitude" in Cornell's words (Cornell 1999, p. 54). Laury Silvers indicates that women's domestic obligations and gendered social norms would have affected their theological perspectives and ritual lives. According to Silvers, if we relate to intersecting socio-historical narratives specifically about women, we can speak about a spirituality particular to women (Silvers 2015, p. 29). Christopher Melchert disagrees with these scholars and relies on content analysis of Ibn alJawzī's (d. 597/1201) biographical dictionary, Sifat al-ṣafwa, to conclude that renunciant and Sufi women during that early stage shared with their male counterparts similar saintly traits, and that both men and women were part of a prevailing pious ideology (Melchert 2016). While Melchert's argument of a similar and prevailing ideology between male and female pietists has some evidence, there is no question that in stories and quoted statements in early Sufi compendia, more pious women were faced with the conflict between one's Sufi devotional life and one's familial-social commitments more strongly than Sufi men. There are no textbooks of early female authors so that we are unable to follow their rhetoric, language and stylistics in comparison with male contemporaries. The earliest Sufi works written by a woman are those of ' $\bar{A}$ 'isha al-Bā'ūniyya (d. 923/1517) of Damascus. Her Kitāb al-muntakhab fì uṣūl al-rutab fí 'ilm al-tașawwuf (Selections on the Principles of the Stations in the Science of Sufism) and other writings provide interesting insights into the author's female identity and do so through her distinguished voice and rhetoric. Her use of emotional-personal language and intensive poetical metaphors essentially differs from her male ancestors (Salamah-Qudsi 2019, pp. 53-55).

The role pious women played in the process of integrating renunciatory practices and mores with mystical conceptions of divine love, longing and unity, from the late eighth century onwards, succeeded in highlighting the active involvement of women in the public space of the Sufi communal life. Their role could be felt in public teaching and learning, in relating and transmitting Sufi doctrinal system and hadith traditions and in taking certain financial responsibilities for Sufi individuals, groups and even more established centers and lodges.

It is worth noting, for example, that if an anecdote focuses on the ritual of remembrance of God's name (dhikr) and involves a woman, it is quite common that the general framework of the story refers to this woman's role as a mother, a sister or a wife. Hukayma alDimashqiyya was the teacher of the famous female mystic of Syria, Rābi'a bint Ismā'îl. Al-Sulamī, in discussing Hukayma, quotes her as having criticized Rābi'a's husband and the latter's decision to take another woman as his wife (al-Sulamī 1999, p. 127). Al-Sulamī's work in general displays the high morality of uncompromising female piety that depicts an iconic image of women who succeeded in managing a deep spirituality alongside a sincere commitment to mothering and wifehood. At times, the focus on more familial issues and ties in the biographies of pious women took less iconic forms. We read, for instance, about women who paid tribute to their children's death. Mu'ädha al-'Adawiyya is described by Ibn al-Jawzī to have asked visiting women not to console her when her husband's son was 
killed but rather congratulate her instead (Ibn al-Jawzī 2000, vol. 2, p. 240). Manfūsa bint Zayd al-Fawāris praises this woman's tenacity and states that enduring the loss of her son is better than the fear of losing him (Ibn al-Jawzī 2000, p. 499). Nusiyya bint Salmān, the wife of Yūsuf b. Asbāt al-Shaybānī (d. 199/815), is quoted by al-Sulamī to have said after she gave birth to a son: "Oh, Lord! You do not see me as someone worthy of Your worship, so You have sought to preoccupy me with a child!." (al-Sulamī 1999, p. 93). 'Athāma bint Bilāl b. Abī al-Dardā' is mentioned as a pious mother who continuously reminded her son of prayer times (al-Sulamī 1999, p. 111).

Without using a woman's social status or engagements as an indicator of a distinctive female piety, such hagiographical references show that a woman's behavioral piety had some distinguishing features both in reality and in literary expression. The ideal of poverty was very often asserted in the biographies of male renunciants and Sufis. The title faqi $r$ itself became a synonym of a Sufi regardless of the perceived or real state of his wealth. It is very interesting to note that this title does not appear in any biography of any women in al-Sulamī's Dhikr al-niswa and in Ibn al-Jawzī' Șifat al-șafwa (in two places of Ibn al-Jawzī's work, the title "female poor" appears; however, it is not used there as an indicator for piety but rather as an actual adjective of two women who are mentioned in the biographical accounts of male pietists. See Ibn al-Jawzī 2000, vol. 1, p. 569; vol. 2, p. 298). As for al-Sulamī, one of his strategies to celebrate the devotional status of many women was to assert that they were wealthy and renowned almsgivers.

Prior to the second half of the seventh/thirteenth century, Sufi communities operated in a ribāt-based framework; different Sufi centers led by charismatic Sufi masters with a group of disciplined Sufis were committed to the collective practices of dhikr and sama $\bar{a}^{\prime}$, of learning sessions and shared fasting meals and journeys (Hofer 2021, pp. 177-78). During the Mamluk period, women's lodges were also founded to provide a residence for divorced and widowed women; however, by the Ottoman conquests, these lodges vanished (Sabra 2021, pp. 33-34). A significant function within the walls of Sufi lodges in general was that of the khädim (lit. servant). The term khidma (service) itself carries various meanings in early Sufi writings. It commonly refers to the domestic and productive activities of Sufi disciples for the benefit of their masters (Chih 2021, p. 199). On some occasions, this term designates the simple act of serving people (Ibn al-Zayyāt 1997, p. 161), or the sincere will of worshipping God (Ibn al-Zayyāt 1997, p. 183). In the sixth/twelfth century monumental manual of 'Umar al-Suhrawardī (d. 632/1234), khidma came to indicate the wish of lay affiliates to "give rest to disciplined Sufis and let them devote themselves to the inner life with God by guaranteeing their living" (al-Suhrawardi 1967, p. 118). Some of these affiliates were in fact wealthy people who had a strong sympathy towards Sufism without being able to formally and regularly comply with all Sufi rituals and duties. They, therefore, chose to bestow upon Sufis donations and endowments (Salamah-Qudsi 2011, pp. 191-92). Biographies and historiographies of early medieval Islam provide us with a large number of references to figures who were involved in khidma, so that they provided certain ribāt communities with the financial support needed for daily life. 'Abd al-Karīm al-Sim'ānī (d. 561/1166), the author of Kitāb al-Ansāb (The Book of Genealogies), refers to Abū al-Ḥasan al-Turjumānī who "served Sufis for sixty years and expended all of his properties that he inherited from his father on them" (al-Sam'āni 1998, vol. 1, p. 479). The prolific historian and biographer Shams al-Dīn al-Dhahabī (d. 747/1346) refers in his Histoire to Munīr b. Muhammad (d. 548/1153), who "used to serve Sufis by earning money and spending it on them" (kāna yakhdimuhum wa-yuhașșilu al-amwāl wa-yunfiqu 'alayhim) (Dhahabī 1989-2004, vol. 37, p. 339).

The term khidma appears very frequently in al-Sulamī's Dhikr al-niswa in the biographies of rich women who spend their wealth on poor Sufis. The meaning of khidma as financial support given to disciplined Sufis could also be applied to the many pious women in al-Sulamī's work. The biographical account of Âmina al-Marjiyya, for instance, opens with the sentence: "She swore herself to the service of Sufis", and ends with an interesting statement of Āmina on service to Sufis (khidmat al-fuqara $\bar{a}^{\prime}$ ) and the illumination of the heart 
that grows from that service (al-Sulamī 1999, pp. 254-55). Fātima al-Khānqahiyya was also introduced by al-Sulamī as a pious woman who "swore herself to the service of Sufis," and he quotes a statement of her in which the term khidma is clearly asserted (al-Sulamī 1999, pp. 256-57). 'A' 'isha bint Ahmad al-Ṭawīl of Merv was the wife of 'Abd al-Wāhid al-Sayyārī (d. 375/985), the renowned mystic of Nishapur. She is presented in al-Sulami's dictionary as the one who "spent more than five thousand dirhams on poor Sufis" (al-Sulamī 1999, pp. 257-59; Cf. al-Sulamī 1999, pp. 236-37, the biography of "Abdūsa bint al-Hārith who "served the poor Sufis for in her town for thirty years"). In the famous historiography of Nishapur al-Muntakhab min Kitāb al-Siyāq li-tārīkh Naysābūr, another pious woman, Sittīk bint Shaykh al-Islām Abī 'Uthmān al-Ṣābūnī (d. 490/1097), is described as a poor Sufi woman (al-faqìra) who "spent all of her wealth on poor and Sufis" (al-Ṣarîfinī 1993, p. 268).

In her introduction to al-Sulamī's Dhikr al-niswa, Rkia Cornell proposes to understand women's altruistic character and distinguished mode of piety based on a servitude that is the essence of women's Sufism. She relates to "a female ethic of chivalry" that parallels a male chivalry tradition known in the history of early medieval Islam as futuwwa (Cornell 1999, pp. 63-70). According to Cornell, the practitioners of this female futuwwa were usually called niswān in al-Sulamī's work in a manner that corresponds with the equivalent term of fityān, the male practitioners of institutionalized chivalry (Cornell 1999, p. 66). The term niswān is actually an enhancement of the general category of niswa, which broadly means women. Cornell relies on another significant work of al-Sulamī, his Kitāb al-futuwwa, to conclude that "by feminizing the term fityān, al-Sulamī sought to impart to the practitioners of female chivalry their own corporate identity" in spite of the lack of evidence for the existence of any formal associations of niswān (Cornell 1999, p. 67). Although I agree with Cornell's reference to the level of enhancement in al-Sulami's use of the term niswān, I do not think that the case for the semantic symmetry between the male and the female concepts has been sufficiently established. The plural form niswān was widely used in classical Arabic literature to convey an enhancement of certain qualities of women, both positively and negatively, and al-Sulami's use of the word fits the broader usage in Arabic literature. Fadl, an Abbasid singing female slave, was depicted as "ash'ar niswān zamānih"̄" (the most skilled poet among her contemporary niswān) (al-Bakrī al-Andalusī n.d., vol. 1, p. 656). Negative implications of the word are also evident (Dhahabī 1989-2004, vol. 33, p. 30). Moreover, among al-Sulamī's women, there are many cases in which almsgiving is asserted while the term niswān does not appear (al-Sulamī 1999, pp. 155, 169). Cornell's translation of the expression "min muta'abbidāt al-niswān" as "practitioner of female chivalry" (Cornell 1999, p. 110) does not belong to the particular context of al-Sulami's text. The translation offered by Laury Silvers to the term muta'abbidāt as "the female vigorous worshippers" is preferable (Silvers 2015, p. 26). Early Sufi women did not practice a distinctive form of chivalry; they did not have an organized form of initiation and self-conscious, collective identity. They did, however, share the same great respect for the economic and household support of fellow Sufis as a means of meaningful engagement with Sufi life and ideals (Ridgeon 2010, p. 34).

Women's wealth helped them practice altruism and effectively struggle against their lower souls that strived for possession and control. Through the act of giving, those women succeeded to present a serious challenge to the world/non-world dichotomy suggested by the Belgian anthropologist Jacque Maquet and quoted by Cornell to explain the development of early Islamic asceticism (Cornel 2019, pp. 84-86). Wealth and donations are in fact prisms of the social and economic involvement in "this world". Instead of remaining abstinent of all worldly affairs, and being fully committed to devotional seclusion, those women chose to be both worldly and non-worldly! They committed themselves to Sufi piety while keeping properties and using them as a means to obtain the blessings of the path as well as an effective and pragmatic contribution to the lives of disciplined Sufis. Women played a fundamental role in the economic settings of early Sufism through this impressive institution of donations and charities. The term arfā al-niswān appears quite often in early textbooks and biographies to signify presents, food, money and alms given 
by women to Sufis. While this famous tradition of accepting women's support is the subject of many warnings by Sufi masters to their adherents to reject this support, these warnings also indicate the popularity of the custom. Stories about pious women whose donations were not accepted by well-known Sufi masters are very common in early Sufi literature. Such stories often have a similar narrative structure that ends with a decisive response made by the female donor who calls out the hypocrisy of the male Sufi who rejected her support while still boasting of his self-sufficiency and abstention from receiving assistance. One example is provided in an anecdote about ' $\bar{A}$ 'isha bint Ahmad al-Ṭawil of Merv, who was 'Abd al-Wāhid al-Sayyārī's wife. She "spent more than five thousand dirhams on the Sufis of her time." When she was told that a particular Sufi refused to accept her gift, she replied: "When the slave seeks glory in his servitude, his foolishness is revealed" (al-Sulamī 1999, p. 259, the English translation of Cornell, p. 258). A similar anecdote relates to Fātima of Nishapur, whose donation to the admired Egyptian mystic Dhū al-Nūn al-Mișrī (d. 246/861) was rejected and sent back (al-Sulamī 1999, p. 143).

While at the first sight, such blunt behavior on the part of male Sufis might be seen as misogynist, a concept whose usage in relation to ancient Islamic models is problematic (Azad 2013, pp. 61-62), this behavior needs to be seen, nonetheless, as part of a wider economic, yet non-gender-oriented approach among early Sufis that views "satisfaction with a determined source for subsistence" (istināma ilā ma'lūm) as a potential malady $(\bar{a} f a)$ for the mystic. Working for a living, begging and accepting charities are all seen as expressions of the Sufi's will to permanently guarantee his living, which might call into question the sincerity of one's dependence on God (tawakkul) (al-Qushayrī 1940, p. 202. On the debates among the early Sufis about accepting donations in general, see Khan 2021, pp. 81-82).

Regardless of their economic status, which could increase their power and authority over their children, mothers in Sufi environments enjoyed great influence and could sometimes navigate the religious/economic decisions of their offspring —even in matters such as making a pilgrimage or roving. Mothers of certain male Sufis had to cope with their children's decision to lead an extremely renunciatory life of actual poverty and harsh physical conditions. Even when those mothers were themselves pietists, they found it very difficult to see their offspring enduring the austerities and brutal demands of the Sufi path. Abū al-'Abbās Aḥmad b. Muhammad b. Masrūq, the early mystic of Baghdad (d. 299/911-12), is reported to have said that his mother wept on Saturday nights when she saw her son's exhaustion due to his challenging devotional exercises (Anșārī Haravī n.d., p. 72). Another anecdote about Ibn Masrūq and his mother is related by al-Khațīb al-Baghdādī:

Abū al-'Abbās b. Masrūq was heard to have said: "I intended to embark on a journey, so I said goodbye to my mother and left the house. One day I found myself stopping at my place and inexplicably unable to make one further step. Immediately I returned back to my house. When the female servant opened the door, I noticed my mother standing in the narrow passage dressed in black clothes. I was frightened to see her in this situation so I asked her: 'O mother! what happened?'. She answered: 'O son! When you left I decided to remain standing in the narrow passage, to fast and to avoid entering the house until you returned'! I knew then that the reason for my inability to go on my journey was for her benefit". (al-Khațīb al-Baghdādī 2001, vol. 6, p. 279).

This anecdote is an example among many others that demonstrate the veneration of mothers, even when it comes at the expense of one's devotional career. Dutifulness towards mothers was not only a statement of compliance with Islamic religious law and sunna, but also one element of the comprehensive system of a mystic's self-discipline (mujāhada). One of the biographical accounts of Abū Nu'aym al-Iṣfahānī's (d. 430/1038) Hilyat al-awliya' ' was devoted to a pious man called Abū 'Abd Allāh Kahmas b. al-Hasan, who was known for his unique sense of duty towards his mother. When a group of his companions came to visit him at his home, his mother, who did not like these people, asked her son not to keep company with them. As a result, he asked his companions not to 
come again (al-Ișfahānī 1997, vol. 6, p. 230). According to Abū Nu'aym and Ibn al-Jawzī, Kahmas did not go on a pilgrimage as long as his mother was alive; only after she died did he go to Mecca, where he spent the rest of his life (al-Ișfahānī 1997, p. 229. For more anecdotes about pietists' dedication to their mothers, see, e.g., Ibn al-Jawzī 1998, pp. 55-56; al-Nawawī 1995, p. 102; al-Tirmidhī 1998, vol. 3, pp. 465-66). Many sheikhs ordered their disciples not to go on pilgrimages or travel for any other purpose as long as they needed to take care of their parents. Abū 'Uthmān al-H̄īrī (d. 298/910), for instance, criticized Muhammad b. 'Abd Allāh al-Farghānī for not asking his mother's permission to travel and for assuming that his mother did not wish him to travel. Farghānī, as a result, decided not to travel as long as his mother was alive. When she died, Farghānī traveled to Nishapur to visit Abū 'Uthmān and became his close disciple (al-Khargūshī 1999, p. 328; Cf. the anecdote about Uways al-Qaran̄ (d. 37/657), a Yemenite contemporary of the Prophet, who was considered by al-Hujwīrī as a mystic whose sincere wish to honor his mother's duty prevented him from meeting the Prophet: al-Hujwīrī al-Jullābī 1926, pp. 99-100). The term haqq al-wālida (lit. mother's right) frequently appears in early Sufi writings to indicate the family constraints to which the Sufi needs to pay attention while progressing on the Sufi path and approaching the crucial need for traveling (al-Hujwīrī al-Jullābī 1926, p. 111; Jāmī 1918, pp. 191, 322; al-Tamīmī al-Fāsī 2002, vol. 2, pp. 106, 129). This was the case of the well-known Sufi master of the sixth/twelfth century 'Abd al-Qādir al-Jīlānī (d. 561/1166), who is reported to entreat his mother, Umm al-Khayr, to let him go to Baghdad. His mother allowed her son to go even while she insisted that she would not see him again until the Day of Judgment (Jāmī 1918, p. 507).

The implications of a mother's right seemed not to be limited to the spiritual needs of Sufis but also have to do with a mother's economic authority and influence. One of the most interesting cases in this regard is that of Abū 'Abd al-Raḥmān al-Sulamī, the prolific Sufi author of Nishapur during the fourth/tenth century. Al-Sulamī's biographers report that his parents were Sufis and that al-Sulamī received his earliest Sufi training from them until his father died and his maternal grandfather Ismā'îl b. Nujayd al-Sulamī (d. 465/976) took over the responsibility of guiding him along the Sufi path. Al-Sulamī's nisba (a term that signifies the individual's ascription to a group, a place, a concept or a profession) was also taken from the Arab tribe of Sulaym through his maternal grandfather. Al-Sulamī himself mentions this nisba in his Tabaqāt (al-Sulamī 1960, p. 476; Hussaini 2011). It was also reported that the grandfather left al-Sulamī a large legacy that enabled him to travel widely, to compose books and even to build a small duwayra (Sufi lodge) for the Sufis of Nishapur.

According to one anecdote transmitted by the famous historian and biographer Shams al-Dīn al-Dhahabī through the authority of al-Sulamī's close disciple Muhammad b. 'Alī al-Khashshāb (died, according to Dhahabī, in 456: Dhahabī 1982-1988, vol. 18, pp. 150-52), al-Sulamī is reported to have said that when his maternal grandfather died, he left behind large areas of land, and that he had no heirs except for his daughter, al-Sulamī's mother. The following is the passage quoted from al-Sulamī through Khashshāb in Dhahabī's work:

An imperious man was in charge of this legacy. Thanks to God's protection, this man was not able to seize anything from the legacy, and he conveyed it all to me. When Abū al-Qāsim al- Nașrābādhī [d. 367/977-78] started undertaking preparations to travel on pilgrimage, I asked my mother's permission to perform a pilgrimage. I sold one sahm [a specific space of land!], and then intended to leave [for Mecca!] in the year 366. My mother said to me: "If you wish to go to God's holy place, then you should totally protect yourself from having your two guardian angels (hâfizāa) write down [in the book of men's actions according to the Muslim faith!] anything that may cause you shame afterwards." (Dhahabī 1982-1988, vol. 17, p. 249).

While asking a mother's permission before performing hajj was a well-documented norm in medieval Islam as the abovementioned examples show, it is very possible that the permission al-Sulamī asks for in the quoted passage relates more to the need to sell the 
inherited land in order to obtain money for his long journey. It should also be noted that when Ibn Nujayd died, al-Sulamī was between thirty-two and forty (Ibn Nujayd died in 365 or 366. Al-Sulamī was born in 325 or, according to other accounts cited by Dhahabī, in 330), making it quite possible that his mother remained domineering regarding her father's properties, and that her son always needed her permission before making use of those properties.

This economic power of Sufis' mothers was sometimes overbearing. Muhammad b. 'Abd al-Karìm al-Tamīmī of Fez (d. 603 or 604/1206 or 1207) in his al-Mustafäd surveys Moroccan Sufi piety in the period between the fourth/tenth and sixth/twelfth centuries. One of the Sufis of Fez mentioned by al-Tamīmī was Ibn al-'Abbās ibn Rashīd, whose mother refused to let him go on pilgrimage during his early youth. It was reported that his mother in a dream heard a voice telling her to permit her son to leave Fez for Mecca. She then asked him to leave all his property and money to her as a condition for the permission. The young man left everything that he inherited to his mother, worked for several days in domestic service, and with the money he earned, succeeded in leaving the city (al-Tamīmi al-Fāsī 2002, vol. 2, pp. 118-20).

Many sisters had enormous economic power that allowed their Sufi brothers to thrive in their devotional lives. In early Sufi hagiographies, we read about sisters who acted as solid support for their renowned Sufi brothers while pursuing their own spiritual careers (al-Sulamī 1999, pp. 123, 193, 195, 217). It is worth noting that in ancient matriarchal societies, it was brothers, not fathers or husbands, who were the natural supporters and protectors of their sisters and their sisters' families and children. This basic feature of primitive societies has survived in different forms in both ancient societies and modern civilizations, even though patriarchy has replaced the more primitive matriarchy (Briffault 1927, vol. 1, 498; Smith 2001, pp. 141-42; 1966, pp. 194-95). Sisters and mothers, rather than wives and daughters, are viewed in anthropological studies of different cultures including Islam as women who would have high social status and thus play influential and notable roles (Sered 2000, p. 11). One example of the strong influence sisters had in early Muslim history can be supported by Ibn 'Asākir in his biography of the sister of 'Abd Allāh b. 'Ämir b. Kurayz. The sister is mentioned as having cursed her brother to the Umayyid khalīfa Mu'āwiya. When Mu'āwiya intended to ride his horse, 'Abd Allāh warned him against this woman who was able to stop the khalifa and overwhelm him with an argument at the end of the story (Ibn 'Asākir 1995-1998, vol. 70, pp. 277-78).

One of the most outspoken examples of Sufi Islam of this period is that of Bishr ibn al-Hārith, who is portrayed in both Sufi and non-Sufi sources as a reclusive mystic who, due to his extreme austere lifestyle, chose to remain celibate his entire lifetime, lived close to his sister's house at times and that she and her sons provided for his sustenance (al-Khatīib al-Baghdādī 2001, vol. 7, 556. On Bishr's style of piety, see Cooperson 1997, pp. 71-101). As previously mentioned, Bishr had three pious sisters who worked in spinning cloth on the roof of their house. He even worked with them for a point until one of his contemporaries, Isḥāq al-Maghāzilī, sent him a letter criticizing him for seeking worldly pleasures instead of practicing a sincerely devotional life (al-Sarrāj al-Tūisi 1914, p. 195). Some stories exist in the sources about sisters who shared the devotional life of their brothers while supporting each other financially as well. The sister of the renowned early mystic Sarī al-Saqați (d. 253/867) also worked in spinning and supported her Sufi brother when he abandoned the trade (al-Khargūshī 1999, p. 367). The sister of Ibrāhīm al-Khawwāṣ (d. 291/903-4), Maymūna, shared both home and devotional life with him (al-Khațib al-Baghdādī 2001, vol. 16, pp. 626-27). Khawāja Muhammad b. Abī Aḥmad al-Chishṭi (d. 411/1020?) is reported by Jāmī (d. 898/1492) to have forsaken marriage until the age of sixty-five, and to have had a sister who served him and worked hard in spinning cloth to provide for him. This sister remained celibate until the age of forty (Jāmī 1918, p. 325).

In fact, subsequent to a marriage ending with widowhood or divorce (of which there were many in medieval Islamic society), many women chose to remain single for a long period of time- even unto death (Rapoport 2005, pp. 31-50). While the vast majority of 
these working women worked at home in the textile industry, other specific gender-related professions were midwives, hairdressers and washers of the dead (Rapoport 2005, p. 34; Goitein 1999, vol. I, p. 128; Shatzmiller 1988). Some of these now single women eagerly sought to improve their socio-economic ties with their brothers in order to fulfill their own inclinations to Sufi piety.

\section{Conclusions}

While women have always been an integral part of the ascetic-mystical tradition of Islam, their involvement in the economics of Sufi life took diverse shapes. Besides the famous female ascetic figures whose poverty and harsh austerities are asserted by later authors and biographers, there are many pious women who succeeded to be engaged in Sufi environments, both partially as patrons who sought baraka and fully as Sufis themselves, through the effective institution of donations and charities. For these women, poverty, while being a principal condition of Sufi piety, seemed not to be strived for in itself, nor a reinforced ideal that restrains the mystic from practicing active altruism.

While many male Sufis preferred to maintain material poverty by not working for subsistence, there was a group of female pietists who were wealthy enough to serve as strong financial backing for their male relatives. This support was very often called khidma. That is to say, the female Sufis discussed in this paper had a very deep understanding of one genuine Sufi saying that describes the true Sufi as the one who, while able to possess anything in this world, is not possessed by anything.

The economic power of Sufi women mainly manifested itself in the domain of familial relationships and kinships. Sisters of famous Sufi figures were working women who succeeded in giving strong backing to their brothers, while mothers enjoyed a great deal of veneration in medieval Islam regardless of any economic capacities. In Sufi contexts, mothers enjoyed an impressive deal of influence over their Sufi children and could even affect the latter's spiritual progress and the timing of life choices.

Funding: This research received no external funding.

Conflicts of Interest: The authors declare no conflict of interest.

\section{References}

Primary Sources

al-Bakrī al-Andalusī, Abū 'Ubayd 'Abd Allāh. n.d. Simț al-la'âlī fì sharh amālī al-Qālī. Edited by 'Abd al-'Azīz al-Maymanī. Beirut: Dār al-Kutub al-'Ilmiyya.

al-Daylamī, Abū al-Hasan 'Alī b. Muhammad. 1977. Sìrat al-shaykh al-kabīr Ab̄̄ 'Abd Allāh Muhammad ibn Khafî̀f al-Shīrāzī. Translated From Persian into Arabic by: Ibrāhīm al-Dusūqī Shatā. Cairo: al-Ḥay'a al-'Āmma li-Shu'ūn al-Mațābi' al-Amīriyya.

al-Ghazālī, Abū Hāmid Muhammad. n.d. Ihȳā' 'ulūm al-dīn. Edited by Muhammad 'Abd al-Malik al-Zughbī. Cairo: Dār al-Manār.

al-Hujwīī al-Jullābī, Abū al-Hasan 'Alī b. 'Uthmān. 1926. Kashfal-mahjūb. Edited by Valentin Zukovsky. Leningrad: Maṭba'at-i Dār al-‘Ulūm-i Ittihād-i Jamāhīr-i Shūravī-yi Sūsyālīstī.

al-Hujwīīī al-Jullābī, Abū al-Hasan 'Alī b. 'Uthmān. 1976. The Kashf al-Mahjūub: The Oldest Persian Treatise on Sufism. Translated by Reynold A. Nicholson. London: Luzac and Company LTD.

al-Iṣfahānī, Abū Nu'aym. 1997. Hillyat al-Awliyā' wa-Tabaqāt al-Asfiyā'. Edited by Muștafā 'Abd al-Qādir 'Ațā. Beirut: Dār al-Kutub al-'Tlmiyya.

al-Khargūshī, 'Abd al-Malik b. Muhammad al-Naysābūrī. 1999. Tahdhīb al-asrār. Edited by Bassām Bārūd. Abū ẓabī: Al-Majma' al-Thaqāîi.

al-Khațīb al-Baghdādī, Aḥmad b. 'Alī. 2001. Ta'rìkh Baghdād. Edited by Bashshār Ma'rūf. Beirut: Dār al-Gharb al-Islāmī.

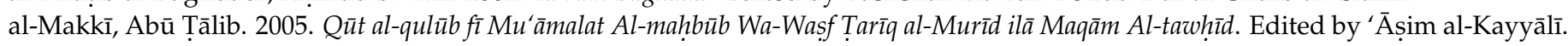
Beirut: Dār al-Kutub al-'Ilmiyya.

al-Nawawī, Yahyā b. Sharaf-al-Dīn. 1995. Riyāẹ Al-sālihīn min Kalām Sayyid Al-mursalīn. Cairo: Maktabat Maṣr.

al-Qushayrī, Abū al-Qāsim 'Abd al-Karīm. 1940. al-Risāla al-Qushayriyya. Cairo: al-Bābī al-Ḥalabī.

al-Sam'ān̄i, 'Abd al-Karīm b. Muḥammad. 1998. Kitāb al-Ansăb. Edited by Muhammad 'Ațā. Beirut: Dār al-Kutub al-'Ilmiyya.

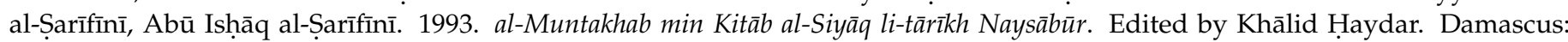
Dār al-Fikr.

al-Sarrāj al-Ṭūsī, Abū Naṣr. 1914. Kitāb al-Luma' fī Al-taṣawwuf. Edited by Reynold A. Nicholson. Leiden: Brill.

al-Suhrawardī, Abū Hafṣ 'Umar. 1967. 'Awārif al-ma'ārif. In Abū Hāmid al-Ghazālì, Ihyyà' 'ulūm al-dīn. Cairo: al-Bābī al-Halabī. 
al-Suhrawardī, ‘Abd al-Qāhir b. 'Abd Allāh Abū al-Najīb. 1977. Ādāb al-murīdīn. Edited by Menahem Milson. Jerusalem: Institute of Asian and African Studies, Hebrew University of Jerusalem.

al-Sulamī, Abū 'Abd al-Rahmmān. 1960. Țabaqāt Al-șūfiyya. Edited by Johannes Pedersen. Leiden: Brill.

al-Sulamī, Abū 'Abd al-Raḥmān. 1976. Jawāmi' ādāb Al-ṣ̂̄fiyya and 'uyūu al-nafs Wa-Mudāwātuhāa. Edited by Etan Kohlberg. Jerusalem: Jerusalem Academic Press.

al-Sulamī, Abū 'Abd al-Raḥmān. 1999. Early Sufi Women: Dhikr An-niswa al-Muta'abbidāt aṣ-Ṣūfiyyāt. Edited and Translated by Rkia Elaroui-Cornell. Louisville: Fons Vitae.

al-Tamīmī al-Fāsī, Abū 'Abd Allāh Muhammad b. 'Abd al-Karīm. 2002. al-Mustafād fì Manāqib al-'ubbād bi-Madīnat Fās wa-mā Yalīhā min al-Bilād. Edited by Muhammad al-Sharīf. Tațān: Kulliyyat al-Ādāb wa-l-`Ulūm al-Insāniyya.

al-Tirmidhī, Muhammad b. 'Īsā. 1998. al-Jāmi' al-kabīr. Edited by Bashshār Ma'rūf. Beirut: Dār al-Gharb al-Islāmī.

Anonymous. 1991. Adab al-mulūk. Edited by Bernd Radtke. Beirut: Beiruter Texte und Studien Herausgegeben vom Orient-Istitut der Deutschen Morgenländischen Gesellschaft in Kommission bei Franz Steiner Verlag Stuttgart.

Anșārī Haravī, 'Abd Allāh. n.d. Ṭabaqāt al-șūfiyya. Edited by Akram Shifā'ī. Tehran: N.p.

Dhahabī, Shams al-Dīn Muhammad b. Aḥmad. 1982-1988. Siyar a'lām al-nubalā'. Edited by Shu'ayb al-Arnā'ūṭ and el. Beirut: Dār al-Risāla.

Dhahabī, Shams al-Dīn Muhammad b. Aḥmad. 1989-2004. Tārīkh al-Islām wa-wafayāt al-mashāhīr wa-l-a'lām. Edited by ‘Umar 'Abd al-Salām al-Tadmurī. Beirut: Dār al-Kitāb al-'Arabī.

Ibn al-Jawzī, Abū al-Faraj 'Abd al-Rahmmān b. 'Alī. 1998. Akhbār al-nisā' (incorrectly attributed to Ibn Qayyim al-Jawziyya). Edited by Ahmad b. 'Alī. Cairo: Dār al-Manār.

Ibn al-Jawzī, Abū al-Faraj 'Abd al-Raḥmān b. 'Alī. 2000. Șifat al-ṣafwa. Edited by Aḥmad b. 'Alī. Cairo: Dār al-Hadīth.

Ibn al-Zayyāt, Abū Ya'qūb Yūsuf b. Yahyā al-Tādilī. 1997. Al-Tashawwwuf ilā Rijāl al-Taṣawwuf wa-Akhbār Abīal-'Abjbās al-Sabtī. Edited by Aḥmad al-Tawfīq. Casa Blanca: Manshūrāt Kulliyyat al-Ādāb.

Ibn 'Asākir, 'Alī b. al-Hasan. 1995-1998. Ta'rīkh Madīnat Dimashq. Edited by Muhibb al-Dīn 'Umar al-'Amrawī. Beirut: Dār al-Fikr.

Jāmī, ‘Abd al-Raḥmān. 1918. Nafahāt al-uns. Edited by Mahdī Pūr. Tehran: Intishārāt Kitābfurūshī Mahmūdī.

Secondary Sources

Azad, Arezou. 2013. Female Mystics in Medieval Islam: The Quiet Legacy. Journal of the Economic and Social History of the Orient 56: 53-88. [CrossRef]

Briffault, Robert. 1927. The Mothers: A Study of the Origins of Sentiments and Institutions. New York: The Macmillan.

Chih, Rachida. 2021. The Social Role of Șūfīs. In Sufi Institutions. Edited by Alexandre Papas. Leiden and Boston: Brill, pp. 187-217.

Cooperson, Micheal. 1997. Ibn Hanbal and Bishr al-Hāfī: A Case Study in Biographical Traditions. Studia Islamica 86: 71-101. [CrossRef]

Cornell, Rkia. 1999. Early Sufi Women. Louisville: Fons Vitae.

Cornel, Rkia. 2019. Rabi'a from Narrative to Myth: The Many Faces of Islam's Most Famous Women Saint Rabi'a al-'Adawiyya. London: OneWorld.

Curry, John, and Erik Ohlander. 2012. Sufism and Society: Arrangements of the Mystical in the Muslim World. Abingdon, Oxon and New York: Routledge.

Dakake, Maria. 2007. Guest of the inmost Heart: Conceptions of the Divine Beloved among Early Sufi Women. Comparative Islamic Studies 3/1: 72-97. [CrossRef]

Digby, Simon. 1986. The Sufi Shaikh as a Source of Authority in Mediaeval India. In Islam et Société en Asie du Sud. Edited by Marc Gaborieau. Paris: Editions de l’École des Hautes Études en Sciences Sociales, pp. 57-77.

El-Cheikh, Nadia Maria. 2002. Women's History: A Study of al-Tanūkhī. In Writing the Feminine: Women in Arab Sources. Edited by Manuela Marén and Randi Deguilhem. London and New York: I. B. Tauris, pp. 129-48.

Goitein, S. D. 1999. A Mediterranean Society. Berkeley: University of California Press, vol. I.

Hofer, Nathan. 2015. The Popularisation of Sufism in Ayyubid and Mamluk Egypt. Edinburgh: Edinburgh University Press.

Hofer, Nathan. 2021. Șūfī Outposts (ribāts). In Sufi Institutions. Edited by Alexandre Papas. Leiden and Boston: Brill, pp. 174-83.

Hussaini, S. Sh. Kh. 2011. Abū 'Abd-Al-Rahmān Solamī. Encyclopædia Iranica I/3: 249-50. An updated version is Available online: http:/ / www.iranicaonline.org/articles/abu-abd-al-rahman-solami-mohammad-b (accessed on 1 May 2021). last updated: July 19, 2011.

Karamustafa, Ahmet. 2007. Sufism: The Formative Period. Berkeley and Los Angeles: University of California Press.

Khan, Hussain Ahmad. 2021. Donations to Șūfīs and Șūfī Institutions. In Sufi Institutions. Edited by Alexandre Papas. Leiden and Boston: Brill, pp. 81-88.

Knysh, Alexander. 2017. Sufism: A New History of Islamic Mysticism. Princeton and Oxford: Princeton University Press.

Marén, Manuela, and Randi Deguilhem. 2002. Introduction: Visibility, Agency and the Consciousness of Women's Actions: To What Extent? In Writing the Feminine: Women in Arab Sources. Edited by Manuela Marén and Randi Deguilhem. London and New York: I. B. Tauris, pp. $x v-x x v i$.

Massignon, Louis. 1954. Essai sur les Origines du Lexique Technique de la Mystique Musulmane. Paris: J. Vrin.

Melchert, Christopher. 2016. Before șüfiyyāt: Female Muslim Renunciants in the 8th and 9th Centuries CE. Journal of Sufi Studies 5: 115-39. [CrossRef] 
Najmabadi, Afsaneh. 2005. Women with Moustaches and Men without Beards: Gender and Sexual Anxieties of Iranian Modernity. Berkeley: University of California Press.

Nizami, Khaliq Ahmad. 1961. Some Aspects of Religion and Politics in India during the Thirteenth Century. Bombay: P. S. Jayasinghe, Asia Publishing House.

Rapoport, Yossef. 2005. Marriage, Money and Divorce in Medieval Islamic Society. New York: Cambridge University Press.

Reinert, Benedikt. 1968. Die Lehre vom Tawakkul in der Klassischen Sufik. Studien zur Sprache, Geschichte und des islamischen Orients, Neue Folge. Band 3. Berlin: W. de Gruyter.

Ridgeon, Lloyd. 2010. Morals and Mysticism in Persian Sufism: A History of Sufi-futuwwat in Iran. London and New York: Routledge.

Roded, Ruth. 1999. Women in Islam and the Middle East: A Reader. London: I. B. Tauris.

Sabra, Adam. 2000. Poverty and Charity in Medieval Islam. Cambridge: Cambridge University Press.

Sabra, Adam. 2021. Economies of Sufism. In Sufi Institutions. Edited by Alexandre Papas. Leiden and Boston: Brill, pp. $27-57$.

Salamah-Qudsi, Arin. 2011. The Idea of Tashabbuh in Sufi Communities and Literature of the Late 6th/12th and Early 7th/13th Century in Baghdad. Al-Qantara XXXII: 175-97. [CrossRef]

Salamah-Qudsi, Arin. 2019. Sufism and Early Islamic Piety: Personal and Communal Dynamics. Cambridge and New York: Cambridge University Press.

Sered, Susan. 2000. Mothers and Icons. Nashim: A Journal of Jewish Women's Studies and Gender Issues 3: 5-14.

Shatzmiller, Maya. 1988. Aspects of Women's Participation in the Economic Life of Later Medieval Islam: Occupations and Mentalities. Arabica 35: 36-58. [CrossRef]

Silvers, Laury. 2015. Early Pious, Mystic Sufi Women. In The Cambridge Companion to Sufism. Edited by Lloyd Ridgeon. New York: Cambridge University Press.

Smith, W. Robertson. 1966. Kinship and Marriage in Early Arabia. New edition with additional notes by the author and by Ignaz Goldziher. Oosterhout: Anthropological Publications.

Smith, Margaret. 2001. Muslim Women Mystics: The Life and Work of Rābi'a and Other Women Mystics in Islam. Oxford: Oneworld. Throsby, David. 2001. Economics and Culture. Cambridge: Cambridge University Press. 